\title{
Effects of Surface Mining on the Vesper Sparrow in the Northern Great Plains
}

TIM A. SCHAID, DANIEL W. URESK, W. LEE TUCKER, AND RAYMOND L. LINDER

\begin{abstract}
A 2-year study was conducted to compare density of vesper sparrow (Pooecetes gramineus) during the breeding season on various aged bentonite clay mine spoils and unmined areas in the Northern Great Plains. The vesper sparrow was one of the most common breeding species with highest densities in grass-sagebrush habitat. Reclaimed and unreclaimed mined spoils had lower sparrow densities which were related to loss of sagebrush habitat. Reserving areas with shrubs between mine spoils, around equipment storage areas, and along haul roads may be necessary during mining and reclamation to attract vesper sparrows in regions where natural regeneration or transplanting of shrubs is difficult.
\end{abstract}

The Northern Great Plains has been subjected to an increasing amount of surface mining within recent years. One important facet of planning mining operations is the re-establishment of wildlife habitat. Quantitative plant ecology-environmental studies (Copeland 1973) are required for planning effective restoration of wildlife habitat. Although several studies deal with the effects of mining on birds in the forested regions of the U.S. (Karr 1968, Copeland and Packer 1972, Terrel and French 1975, Yahner et al. 1975,

\footnotetext{
Authors are graduate research assistant, South Dakota State University, Brookings (present address is: Burns \& McDonnell, P.O. Box 173, Kansas City, MO. 64141): research scientist, Rocky Mountain Forest and Range Experiment Station, Rapid City. S. Dak. 57701: experiment station statistician. South Dakota State Univ., Brookings: and Unit leader, South Dakota Cooperative Wildlife Research Unit. Brookings.

This research was performed in cooperation with South Dakota Cooperative Wildlife Research Unit. Brookings (South Dakota State University. South Dakota Department of Game, Fish and Parks. U.S. Fish and Wildlife Service. and the Wildlife Management Institute, cooperating) and USDA Forest Service, Rocky Mountain Forest and Range Experiment Station in Rapid City under project 16-606CA. The manuscript was published under the South Dakota Agricultural Experiment Station Journal Series number 1744.

Authors express our sincere gratitude and appreciation to Dr. Ardell Bjugstad, and Dr. Keith Severson, Rocky Mountain Forest and Range Experiment Station, U.S. Forest Service. Rapid City, for their assistance and advice during the field investigations and preparation of this manuscript. We also thank Dr. L.B. Best and Dr. J.T. Rotenberry for reviewing and commenting on earlier drafts of the manuscript.

Manuscript received May 15.1982.
}

Whitmore and Hall 1978), little information is available of the impacts of surface mining on avian species of the Northern Great Plains.

One common breeding bird in the grass-sagebrush habitat mined for bentonite clay is the vesper sparrow. This paper compares densities of vesper sparrow in unmined grass-sagebrush habitat with reclaimed and unreclaimed mined areas.

\section{Study Area}

The study area paralleled U.S. Highway 212 and the Belle Fourche River and extended northwest from Belle Fourche, $S$. Dak., to Colony, Wyo. A major mining haul road, approximately $18 \mathrm{~km}$ in length, passed through the study area from Belle Fourche to Colony. The study area contained several areas totaling more than 224 ha of unmined grass-sagebrush habitat in addition to a 160 ha area of unreclaimed bentonite spoils, and 128 ha of reclaimed bentonite spoils. The unreclaimed area included numerous bentonite spoils and mine pits up to 40 years old. The pits and spoils were scattered in what appeared to be an erratic pattern, with occasional remnants of unmined grass-sagebrush habitat between the spoils and pits. Many of the pits contained water. The reclaimed portion of the study area included recontoured and revegetated pits and spoils. Reclamation was completed 3 to 10 years prior to this study. Six of the larger pits were left as stock ponds $\geq 50 \mathrm{~m}^{2}$ in size. Recla mation consisted of recontouring mine spoils and revegetating with native grasses (green needlegrass Stipa viridula, Agropyron spp.). Crested whcatgrass (Agropyron cristatum) was also planted. No remnants of grass-sagebrush habitat existed on the reclaimed area. The reclaimed and unreclaimed areas were bordered by unmined land with a grass-sagebrush cover.

Soils of the study area arc acidic and within a region classified as a Grummit-shale land association (Johnson 1976). Climate is continental with cold winters and hot summers. Average annual precipitation is $39 \mathrm{~cm}$ and snowfall averages $53 \mathrm{~cm}$ per year (Johnson 
Table 1. Independent variables used in multiple stepwise forward regression analysis.

Variable $(\%=$ Frequency of occurrence)

$\%$ Vegetated area

$\%$ Unvegetated area

$\%$ Persistent litter

$\%$ Litter (persistent + nonpersistent)

$\%$ Forbs

$\%$ Shrubs

$\%$ Warm season grass

\% Bromus japonicus

$\%$ Hordeum jubatum

$\%$ Koeleria cristata

$\%$ Poa spp.

$\%$ Bouteloua gracilis

$\%$ Stipa viridula

$\%$ Artemisia tridentata

\% Atriplex spp.

$\%$ Agropyron spp.

\% Kochia spp.

Mean surface area of water $\left(\mathrm{m}^{2}\right)$

Average height of vegetation (cm)

Plant species diversity

1976). From April-July in 1977 precipitation was $16 \mathrm{~cm}$ (National Oceanic Atmospheric Administration 1977). In 1978, however, 29 $\mathrm{cm}$ of precipitation was recorded from April-July (National Oceanic Atmospheric Administration 1978).

Vegetation in the study area was characteristic of the mixed grass prairie association described by Johnson and Nichols (1970). Big sagebrush (Artemisia tridentata) was the major shrub; saltbush (Atriplex spp.), rabbitbrush (Chrysothamnus nauseosus), and broom snakeweed (Gutierrezia sarothrae) were less common. Predominant native grasses were western wheatgrass (Agropyron smithii), prairic junegrass (Koelaria cristata), buffalograss (Buchloe dactyloides), and blue grama (Boutelowa gracilis). Bluegrass (Poa spp.), brome grass (Bromus spp.), green needlegrass, and foxtail barley (Hordeum jubatum) were widespread through the study area. Nomenclature is according to Johnson and Nichols (1970).

\section{Methods}

\section{Selection of Study Plots}

The study area was divided into 3 habitat treatments: (1) unmined sagebrush-grassland, (2) reclaimed, and (3) unreclaimed bentonite spoils. A total of $92(200 \times 200 \mathrm{~m})$ study plots were selected among the treatments: 56 study plots were located on the unmined sagebrush-grasslands; 16 plots on reclaimed bentonite spoils, and 20 plots on unreclaimed bentonite spoils. All study plots were selected by treatment based on similar habitat characteristics.

\section{Habitat Measurements}

Vegetation was sampled in each of the 92 study plots using 5 randomly located 0.04 ha circles (James and Shugart 1970). A steel rod $(1 \mathrm{~m} \times 6.3 \mathrm{~mm})$ as described by Wiens (1969) was lowered vertically into the vegetation to determine sample points along 2 perpendicular, north-south and east-west, lines $(+)$ through the circle. The rod was lowered just off the toe of the observer at each alternate step. The distance from the ground to where vegetation contacted the rod was measured and recorded at each sample point. The species of vegetation contacting the rod was also recorded. Each 0.04 ha circle had 20 sample points, 10 on each perpendicular line, for a total of 100 points/plot. The perpendicular lines within the circles were walked from the center outward, 5 points on each side of the center, so the sample points would be evenly distributed across the circle.

Percent frequency of occurrence (total hits out of 100 possible) was calculated for all plant species. Frequency was calculated using vegetation touching the rod (hits) at the highest point. Average height of vegetation and plant species diversity (Shannon and Weaver 1963) were calculated using all vegetation hits. The percent frequency of persistent litter occurrence was also calculated. Persistent litter consisted of dead plant or animal material lasting in the field longer than 1 year. Non-persistent litter included such materials lasting 1 year or less. The surface area of water within the habitat treatments was visually estimated in 1977. An open-site alidade and plane table (Lind 1974) were used to measure surface area of water in 1978.

\section{Bird Counts}

Birds were counted on each of the 92 plots from 24 May-17 July 1977 and 1978 using a transect method described by Emlen (1971). Transects were $200 \times 200 \mathrm{~m}$. The center of a transect bisected each study plot. A mean vesper spar row density was calculated for each transect. Counts were made on all transects once a week between 0600-0900 (MDT), except on rainy or windy days.

\section{Analysis}

Orthogonal $t$-tests (Steel and Torrie 1960) were used to test for significant statistical differences $(P \leq 0.01)$ in bird density between habitat treatments by year. Mean density of vesper sparrows was tested for all transects by treatment for the period 24 May-17 July 1977 and 1978 . The order in which the habitat category means were tested for significant differences was chosen to reflect differences between mined and unmined categories. Therefore, other combinations of means are possible. Stepwise forward multiple regression analysis (Nie et al. 1975) was used to identify a set of habitat variables that accounted for a significant $(P \leq 0.10)$ portion of the variation in the density of vesper sparrows. A separate analysis was performed for each of the 3 habitat treatments for 1977 and 1978. Percent frequency of occurrence for the plants that occurred with the vesper sparrow on $50 \%$ of the plots within a habitat treatment was used as independent variables (Table 1 ). The $50 \%$ frequency of

Table 2. Vegetation variables for unmined grass-sagebrush habitat and bentonite mine spoils measured May 24-July 17, 1977 and 1978 , near Colony, Wyo.

\begin{tabular}{|c|c|c|c|c|c|c|}
\hline \multirow[b]{2}{*}{ Variable } & \multicolumn{2}{|c|}{$\begin{array}{l}\text { Mined unreclaimed } \\
\qquad \mathbf{N}=20^{1}\end{array}$} & \multicolumn{2}{|c|}{$\begin{array}{l}\text { Mined reclaimed } \\
\quad N=16\end{array}$} & \multicolumn{2}{|c|}{$\begin{array}{l}\text { Unmined grass-sagebrush } \\
\qquad N=14\end{array}$} \\
\hline & 1977 & 1978 & 1977 & 1978 & 1977 & 1978 \\
\hline$\%$ Forbs $^{2}$ & $3 \pm 3^{3}$ & $8 \pm 6$ & $13 \pm 8$ & $13 \pm 9$ & $3 \pm 2$ & $16 \pm 10$ \\
\hline$\%$ Shrubs $^{2}$ & $3 \pm 5$ & $2 \pm 3$ & $0 \pm 0$ & $0 \pm 0$ & $6 \pm 5$ & $5 \pm 4$ \\
\hline$\%$ Grasses $^{2}$ & $7 \pm 10$ & $5 \pm 7$ & $21 \pm 10$ & $34 \pm 22$ & $23 \pm 9$ & $37 \pm 18$ \\
\hline Total vegetated area & $14 \pm 12$ & $14 \pm 10$ & $34 \pm 10$ & $42 \pm 24$ & $32 \pm 8$ & $47 \pm 19$ \\
\hline Average height of vegetation $(\mathrm{cm})$ & $10 \pm 7$ & $8 \pm 3$ & $14 \pm 6$ & $14 \pm 4$ & $8 \pm 4$ & $15 \pm 4$ \\
\hline Plant species diversity & $0.5 \pm 0.3$ & $0.6 \pm 0.4$ & $0.7 \pm 0.2$ & $0.7 \pm 0.2$ & $0.8 \pm 0.2$ & $0.9 \pm 0.4$ \\
\hline
\end{tabular}

$1 \mathbf{N}=$ Number of plots

$2 \%=$ Frequency of occurrence

${ }^{3}$ Mean \pm standard deviation

Thotal frequency of occurrence of forbs, shrubs, and grass. Columns do not add to total because of variance term between plots. 
occurrence level was chosen to avoid inadvertent correlations with infrequently occurring plants.

\section{Results and Discussion}

\section{Vegetation}

The total frequency of occurrence of all species of vegetation was generally greater in the reclaimed and grass-sagebrush treatments than in unreclaimed mined areas (Table 2). Grasses and forbs were prevalent in grass-sagebrush habitat and the reclaimed areas but occurred less frequently in unreclaimed bentonite mine spoils. No shrubs were found in the reclaimed treatment. Big sagebrush was common in the grass-sagebrush habitat but less common in the unreclaimed bentonite spoils. Within the unreclaimed treatment, grass-sagebrush habitat was occasionally found between mine spoils and other areas where soils were apparently undisturbed.

\section{Bird Counts}

Density of vesper sparrows was greatest in unmined grasssagebrush and similar in the mined treatments (Table 3). Although vesper sparrows were occasionally identified by song on reclaimed bentonite spoils, singing males were not consistently observed in one region of a plot as they often were in the other treatments. Several vesper sparrow nests were found while walking bird transects and measuring vegetation in the grass-sagebrush and unreclaimed spoils. All nests were on the ground under big sagebrush. Vesper sparrow nests were not observed in the reclaimed spoils.

Table 3. Mean vesper sparrow density/40 ha on grass-sagebrush habitat and bentonite mine spoils during May 24-July 17, 1977 and 1978, near Colony, $\mathbf{w}_{\text {yo }}$.

\begin{tabular}{|c|c|c|c|c|}
\hline \multirow[b]{2}{*}{ Treatment } & \multicolumn{2}{|r|}{1977} & \multicolumn{2}{|r|}{1978} \\
\hline & $\mathbf{N}^{1}$ & $\bar{x} \pm$ S.D. & $\mathbf{N}^{\prime}$ & $\bar{x} \pm$ S.D. \\
\hline Unreclaimed & 20 & $5 \pm 6$ & 20 & $4 \pm 7$ \\
\hline Reclaimed & 16 & $5 \pm 1$ & 16 & $3 \pm 2$ \\
\hline Mine spoils ${ }^{2}$ & 36 & $5 \pm 8$ & 36 & $4 \pm 5$ \\
\hline Unmined grass-sagebrush & 42 & $14 \pm 9 * * * 3$ & 56 & $25 \pm 14^{* * * 3}$ \\
\hline
\end{tabular}

Number of transects

${ }^{2}$ Unreclaimed + Reclaimed (pooled)

3*** Mean is significantly different from mine spoils at $P \leq 0.001$

This study clearly shows that the unmined grass-sagebrush treatment had a greater population of vesper sparrows than the mined treatments. The lower vesper sparrow density in mincd areas can be explained in part by the reduction or elimination of big sagebrush as a result of mining and reclamation procedures (Table 2 ). Vesper sparrows used sagebrush for nesting cover and singing perches. In addition, vesper sparrows were often observed perched on sagebrush feeding on the seeds of bluegrass and prairie junegrass that were protruding through the sagebrush. Results of regression analysis reflected the importance of sagebrush as related to vesper sparrows. Big sagebrush entered the regression equation in 1977 and 1978 first and accounted for $57 \%(\mathrm{~N}=20, P<0.05)$ and $85 \%(\mathrm{~N}=20, P<0.05)$ of the variation in vesper sparrow density, respectively, on unreclaimed bentonite mine spoils (Table 4 ).

The effects of reduced sagebrush on vesper sparrow populations have been studied by others. Fautin (1975) reported that vesper sparrows in Wyoming occurred on study plots where some sagebrush was present but were not observed on grass-cactus areas. Best (1972) reported no difference between the numbers of breeding pairs of vesper sparrows on land in Montana sprayed with 2,4-D for sagebrush control and unsprayed land. Unlike the present study, however, sagebrush in Montana was not physically removed and still provided cover for nesting sparrows even when the shrub was dead.

Green needlegrass, which is utilized as food by the vesper sparrow (Best 1972), may partially account for the occurrence of vesper sparrows in the reclaimed spoils where green needlegrass was used for revegetation. Percent frequency of occurrence of green needle-
Table 4. Independent variables used in forward multiple stepwise regression analysis explaining significant variation of vesper sparrow density in unreclaimed habitat during 1977 and 1978, $N=20$.

\begin{tabular}{lcc}
\hline \hline Variable & $\begin{array}{c}\text { Regression } \\
\text { coefficient }\end{array}$ & $\begin{array}{c}\text { Accumulative } \\
R^{2}\end{array}$ \\
\hline 1977 & 0.10 & \\
\% Artemisia tridentatal & 0.95 & 0.57 \\
Plant species diversity & & 0.69 \\
1978 & 0.27 & \\
\% Artemisia tridentata & & 0.85 \\
\% Atriplex spp. & -0.07 & 0.87 \\
\% Poa spp. & 0.09 & 0.88 \\
\% Agropyron spp. & 0.09 & 0.93 \\
\hline
\end{tabular}

$1 \%=$ Frequency of occurrence

${ }^{2}$ Significant at $P \leq 0.05$

grass was the first variable to enter the regression equation in 1977 and accounted for $40 \%(\mathrm{~N}=16, P \leq 0.01)$ of the variation in vesper sparrow density on reclaimed bentonite spoils (Table 5). Significant variation was not explained in the reclaimed treatment during 1978. Within the grass-sagebrush treatment, the vesper sparrowsagebrush relationship was not clear. Surface area of water and percent frequency of occurrence of forbs, persistent litter, and shrubs, accounted for $95 \%$ of the variation in the density of vesper sparrows $(N=14, P \leq 0.001)$ in 1977 (Table 6). The frequency of occurrence of shrubs included big sagebrush and less common species like broom snakeweed, rabbitbrush, and saltbush. Persistent litter in grass-sagebrush habitat was predominately sagebrush litter. In 1978, the frequency of shrub occurrence did not account for significant variation in vesper sparrow density within the grasssagebrush treatment.

Table 5. Independent variables used in forward multiplestepwise regression analysis explaining significant variation of vesper sparrow density in reclaimed habitat during $1977, \mathrm{~N}=16$.

\begin{tabular}{lcc}
\hline \hline Variable & $\begin{array}{c}\text { Regression } \\
\text { coefficient }\end{array}$ & $\begin{array}{c}\text { Accumulative } \\
R^{2 * * 3}\end{array}$ \\
\hline 1977 & & \\
\% Stipa viridula ${ }^{1}$ & 0.09 & 0.40 \\
\% Hordeum jubatum & -0.79 & 0.46 \\
\% Kochia sp. & 0.27 & 0.49 \\
\% Bromus japonicus & 0.09 & 0.54 \\
\% Litter & -0.09 & 0.58 \\
\% Unvegetated area & -0.04 & 0.66 \\
Plant species diversity & -0.85 & 0.73 \\
\% Agropyron spp. & -0.32 & 0.79 \\
Surface area of water $\left(\mathrm{m}^{2}\right)$ & $<0.01^{2}$ & 0.84 \\
\% Warm season grasses & 0.06 & 0.95 \\
\hline
\end{tabular}

$1 \%=$ Frequency of occurrence

2Surface area of water $\left(\mathrm{m}^{2}\right)=0.00008$

3** Values significant at $P \leq 0.01$

Less variance being explained by shrubs in unmined grasssagebrush habitat than mined areas suggests forbs and grasses were also important. When shrubs were plentiful (i.e., grass-sagebrush), the importance of shrubs to the vesper sparrows was not as apparent through multiple regression analysis as when shrubs were sparse (i.e., unreclaimed spoils). Rotenberry and Wiens (1980) suggested that birds do not select habitats based on subtle variation in vegetation parameters. Therefore, within the unmincd grasssagebrush habitat where shrubs were plentiful, the frequency of shrub occurrence would not be a good predictor for vesper sparrow density and would not be expected to account for a significant proportion of the variation.

Bent (1962) reported that vesper sparrows were found in a grass habitat with sparse sagebrush. Whitmore and Hall (1978) found vesper sparrows were common on reclaimed a reas in West Virginia that had open grasslands bordered by forested areas. Rotenberry 
Table 6. Independent variables used in forward multiple stepwise regression analysis explaining significant variation of vesper sparrow density in unmined habitat during 1977 and $1978, N=14$.

\begin{tabular}{lcc}
\hline \hline Variable & $\begin{array}{c}\text { Regression } \\
\text { coefficient }\end{array}$ & $\begin{array}{c}\text { Accumulative } \\
R^{2}\end{array}$ \\
\hline 1977 & & \\
Surface area of water $\left(\mathrm{m}^{2}\right)$ & 0.001 & 0.790 \\
\% Forbs & -0.525 & 0.854 \\
\% Persistent litter & 0.135 & 0.894 \\
\% Shrubs & -0.590 & $0.947^{* * *}$ \\
1978 & & \\
\% Koelaria cristata & & \\
$\%$ Forbs & 0.302 & 0.704 \\
\% Bromus japonicus & -0.397 & 0.873 \\
Average height of vegetation (cm) & -0.100 & 0.886 \\
\% Bouteloua gracilis & 0.360 & 0.901 \\
\% Unvegetated area & 0.071 & 0.909 \\
\% Agropyron spp. & 0.271 & 0.922 \\
\% Poa spp. & 0.122 & 0.930 \\
\% Vegetated area & -0.286 & 0.935 \\
\hline
\end{tabular}

$1 \%=$ Frequency of occurrence

***Values significant at $P \leq 0.001$

**Values significant at $P \leq 0.01$

and Wiens (1980) found vesper sparrows were positively correlated with forb cover $(P<0.001)$ on montane sites; however, the authors did not state if shrubs were nearby. Vesper sparrows also were positively correlated $(P \leq 0.05)$ with a heterogeneity index for forbs and shrubs (Rotenberry and Wiens 1980).

Vesper sparrows used sagebrush for nesting cover, singing perches, and feeding. The large amount of variation in vesper sparrow density accounted for by sagebrush in unreclaimed mine spoils indicated the importance of the habitat remaining in mined areas. However, the natural regeneration of woody plants on bentonite mine spoils is often sporadic or nonexistent (Bjugstad 1978). The transplanting of shrubs to reclaimed mine spoils in the Northern Great Plains has been difficult (Orr 1977, Bjugstad 1979). Bentonite spoils within the study area were reclaimed without shrubs because of the landowner's preference for grazing of livestock. In addition, the cost and poor success of transplanting shrubs was a major factor.

Where transplanting or natural regeneration of shrubs is difficult, maintaining areas of shrubs along haul roads and around equipment storage areas during mining activities may be necessary. Because of the erratic location of strip-pits in bentonite mining, it may also be possible to reserve patches of shrubs between strip-pits or mine spoils. This may be the only reasonable approach to provide habitat for the same birds that are found on unmined areas. Leaving patches of sagebrush during mining was not tested within the study area; however, patches of sagebrush remaining in the old spoils did attract vesper sparrows.

\section{Conclusion}

This study indicated that, in addition to recontouring and reseeding mined grassland-sagebrush areas with grasses, shrubs should be present to prevent a substantial reduction in vesper sparrow density. Vesper sparrows were the most common breeding bird found in unmined areas. Density of vesper sparrows on areas mined for bentonite clay was significantly lower than on unmined grass-sagebrush habitat. The lower density on bentonite spoils was attributed to the sparsity of shrubs, primarily sagebrush. Elimination of sagebrush during mining and no reclamation for shrubs left the bentonite spoils virtually without shrub species.

Conditions in the Northern Great Plains (e.g., soils, climate) often do not allow for the economical transplantation or natural re-establishment of shrubs to reclaimed areas. As an alternate, or in addition to transplanting shrubs, patches of sagebrush or other shrubs (when present) should be left along mining haul roads, between mine spoils, and around equipment and supply storage areas during mining and reclamation operations.

\section{Literature Cited}

Bent, A.C. 1962. Life histories of North American shore birds. U.S. Nat. Mus. Bull. 142. Part 2.

Best, L.B. 1972. First-year effects of sagebrush-control on two sparrows. J. Wildl. Manage. 36:534-544.

Bjugstad, A.J. 1978. Re-establishment of woody plants on mine spoils and management of mine water impoundments: an overview of Forest Service research on the Northern High Plains. P. 3-12 In: R.A. Wright, ed. The reclamation of disturbed arid lands. Univ. of New Mexico Press, Albuquerque.

Bjugstad, A.J. 1979. Bentonite mine spoil and pit reclamation: a major research problem. P. 1-18 In: Proc. of the Mineral Waste Stabilization Liaison Committee. Erie Mining Co., Eveleth, Mont.

Copeland, O.L. 1973. Mining impacts and resource management. Trans. North Amer. Wildl. and Nat. Resour. Conf. 38:111-120.

Copeland, O.L., and P.E. Packer. 1972. Land use aspects of the energy crisis and western mining. J. Forest. 70:671-675.

Emlen, J.T. 1971. Population densities of birds derived from transect counts. Auk 88:323-342.

Fautin, R.W. 1975. The terrestrial vertebrate fauna of the Atlantic Richfield Company's Black Thunder lease property in Campbell County, Wyoming. P. 635-650 $\mathrm{m}$ : W.F. Clark, ed. Proc. Sp. of the Fort Union Coal Field Symposium. Vol. V, Terrestrial Ecosystem. Montana Academy of Science, Billings.

James, F.C., and H. Shugart. 1970. A quantitative method of habitat description. Audubon Field Notes 24:727-736.

Johnson, P.R. 1976. Soil survey of Butte County, South Dakota. USDA, SCS, South Dakota Agr. Exp. Sta.

Johnson, J.P., and J.R. Nichols. 1970. Plants of South Dakota grasslands: a photographic study. South Dakota State Univ. Agr. Exp. Sta. Bull. 566.

Karr, J.R. 1968. Habitat and avian diversity on strip-mined land in eastcentral Illinois. Condor 70:348-359.

Lind, 0.T. 1974. Handbook of common methods in limnology. C.V. Mosby Co., St. Louis.

National Oceanic Atmospheric Administration. 1977. Climatological Data. Annual summary, South Dakota. Environ. Data Service, Nat. Climatic Center, Asheville, N.C. 82(13): 1-17.

National Oceanic Atmospheric Administration. 1978. Climatological data. Annual summary, South Dakota. Environ. Data Service, Nat. Climatic Center, Asheville, N.C. 83:1-17.

Nie, N.H., C.H. Hull, J.C. Jenkins, K. Steinbrenner, and D.H. Bent. 1975. SPSS: statistical package for the social sciences. Second Edition. McGraw-Hill, New York.

Orr, H.K. 1977. Re-establishment of wooded waterways and associated upland shrub communities in surface mining areas of the northwestern Great Plains. P. 235-243 In: Fifth Symposium, Surface Mining and Reclamation, NCA/BCR Coal Conf. and Exp. IV. Louisville, Ky.

Rotenberry, J.T., and J.A. Wiens. 1980. Habitat structure, patchiness, and avian communities in North American steppe vegetation: a multivariate analysis. Ecology 61:1228-1250.

Shannon, C.E., and W. Weaver. 1963. The mathematical theory of communication. Univ. of Illinois Press, Urbana.

Steel, R.G.D., and J.H. Torrie. 1960. Principles and procedures of statistics. McGraw-Hill, New York.

Terrel, T.L., and T. French. 1975. Wintering bird populations on coal strip-mines in north central Alabama. J. Alabama Acad. Sci. 46:1-13.

Wiens, J.A. 1969. An approach to the study of ecological relationships among grasslands birds. A.O.U. Ornithol. Monogr. 8:1-93.

Whitmore, R.C., and G.A. Hall. 1978. The response of passerine species to a new resource: reclaimed surface mines in West Virginia. Amer. Birds 32:6-9.

Yahner, R.H., A.W. Garton, and J.C. Howell. 1975. Breeding avifauna associated with two strip mine areas. J. Tennessee Acad. Sci. 50:95-98. 